\title{
Pengembangan Big Book Storytelling Dwibahasa untuk Meningkatkan Literasi Anak Usia Dini
}

\author{
Yansyah $^{\circledR}{ }^{\bowtie}$, Jamiatul Hamidah ${ }^{2}$, Lita Ariani ${ }^{3}$ \\ Pendidikan Bahasa Inggris, Universitas Muhammadiyah Banjarmasin, Indonesia(1) \\ Pendidikan Bahasa Indonesia, Universitas Muhammadiyah Banjarmasin, Indonesia(2) \\ Psikologi, Universitas Muhammadiyah Banjarmasin, Indonesia(3) \\ DOI: $\underline{10.31004 / o b s e s i . v 6 i 3.1779}$
}

\begin{abstract}
Abstrak
Pendidikan literasi saat ini marak digaungkan karena memiliki peran penting bagi masa depan anak. Namun, berbanding terbalik dengan teori, praktik pendidikan literasi di lapangan masih memerlukan perhatian. Penelitian ini bertujuan untuk mendesain dan mengembangkan big book storytelling dwibahasa untuk mendukung perkembangan literasi anak usia dini. Menggunakan bahasa Indonesia dan bahasa Inggris, big book disampaikan dengan teknik mendongeng yang bertujuan untuk mengembangkan kosakata anak dan minat mereka terhadap kedua bahasa tersebut. Penelitian ini menggunakan desain penelitian pengembangan berdasarkan model Reeves (2006) dan melibatkan 74 guru taman kanak-kanak yang ada di Banjarmasin. Data dikumpulkan dengan teknik wawancara dan observasi. Tahapan pengembangan terbagi menjadi empat fase: analisis kebutuhan, pengembangan produk, implementasi, dan refleksi. Validasi ahli menunjukkan bahwa big book yang dikembangkan telah layak dan dapat digunakan untuk anak usia dini baik dari segi psikologis, pembelajaran, kualitas fisik, dan bahasa. Anak-anak juga menikmati belajar dengan menggunakan media ini berdasarkan hasil observasi.
\end{abstract}

Kata Kunci: big book dwibahasa; pendidikan dwibahasa; literasi anak usia dini; mendongeng.

\begin{abstract}
Literacy education gains more popularity today for its significant role in children's future. However, different from the theory, the practice of literacy education in reality still needs some improvements. This research aims to design dan develop bilingual big books storytelling to support the development of early childhood literacy. Using Bahasa Indonesia and English, it is delivered in a storytelling technique so the children are expected to develop their vocabulary and interest to learn these two languages. The design of this study is design-based research using Reeves model (2006). Seventy-four teachers teaching in the kindergartens were invited to join this project. The data were gathered through interview and observation. The development process consisted of four stages: need analysis, product development, implementation, and reflection. Experts' validation showed that the big book storytelling was appropriate and able to use for teaching young learners based on the consideration of psychological, learning, physical quality, and language aspects of the media. Young learners also enjoyed learning using the bilingual big book based on the results of observation.

Keywords: bilingual big book; bilingual education; early childhood literacy; storytelling.
\end{abstract}

Copyright (c) 2021 Yansyah, et al.

$\triangle$ Corresponding author:

Email Address : yansyah.hamarung@gmail.com

Received 20 May 2021, Accepted 19 September 2021, Published 25 September 2021 


\section{PENDAHULUAN}

Pendidikan literasi semakin marak digalakkan sekarang ini. Literasi memiliki cakupan makna yang luas, namun European Literacy Policy Network mendefinisikannya sebagai kemampuan membaca dan menulis serta kemampuan memahami dan menggunakan informasi dari semua jenis media (Montoya, 2018). Kemampuan literasi sangat penting dibangun sejak dini karena merupakan faktor penentu literasi individu ketika dia remaja dan dewasa. Suggate et al., (2018), berdasarkan penelitian yang dilaksanakan selama 15 tahun, menemukan bahwa terdapat hubungan antara perolehan kosakata, literasi, dan kemampuan oral anak hingga dia berusia remaja. Oleh sebab itu, pendidikan literasi memang sebaiknya diperkenalkan sejak dini dengan menggunakan teknik dan media yang sesuai perkembangan anak.

Masa anak-anak seringkali disebut sebagai masa emas perolehan bahasa. Pada masa ini pendidikan dwibahasa atau bilingual bisa dikenalkan kepada anak sebagai bagian dari pendidikan literasi. Penelitian menunjukkan bahwa anak-anak dengan kemampuan dwibahasa memiliki kemampuan memecahkan masalah lebih baik daripada anak-anak monolingual (Bialystok, 1999). Hopp et al., (2019) juga menyimpulkan bahwa kemampuan dwibahasa berkaitan dengan prestasi anak dalam pembelajaran bahasa asing. Secara specific, Kieseier (2021) menemukan bahwa anak-anak bilingual memiliki akurasi pengucapan bahasa Inggris yang lebih baik dibandingkan anak-anak monolingual. Dengan berbagai keuntungan ini, pendidikan dwibahasa bisa dipertimbangkan untuk anak-anak dengan harapan perolehan dan pembelajaran bahasa asing di tingkatan sekolah selanjutnya menjadi lebih baik. Namun, tentu saja pembelajaran ini harus dibatasi sesuai dengan tingkat kemampuan mereka.

Sebagai negara dengan keragaman budaya dan bahasa, maka bilingualisme bukan merupakan hal yang asing di Indonesia. Izzak (2009) menyebutkan bahwa masyarakat Indonesia paling tidak menguasai dua bahasa, yaitu bahasa daerah sebagai bahasa keseharian dan bahasa Indonesia sebagai bahasa nasional. Dalam konteks sekolah, bahasa asing seperti bahasa Arab dan Inggris juga dikenalkan pada anak-anak mengingat kebutuhan untuk bisa berkomunikasi di dunia internasional juga semakin meningkat. Pendidikan dwibahasa di Indonesia meskipun memiliki berbagai tantangan, namun masyarakat memandang bahwa pendidikan seperti ini diperlukan dan direkomendasikan untuk dikembangkan oleh pemerintah mengingat berbagai keuntungan bagi individu serta berdasarkan tuntutan era globalisasi (Jayanti \& Sujarwo, 2019).

Pendidikan dwibahasa bagi anak usia dini memerlukan perlakuan khusus mengingat tahapan perkembangan mereka. Arumsari et al., (2017) merekomendasikan tiga hal jika ingin mengenalkan bahasa asing pada anak, yaitu guru yang berkualitas yang memahami teknik mengajar bagi anak, sumber dan fasilitas belajar yang memadai dan memenuhi syarat, serta kurikulum yang baik, sederhana, dan atraktif. Salah satu media pembelajaran yang bisa digunakan untuk tujuan literasi dwibahasa ini adalah big book. Big book merupakan sebuah buku besar dengan cerita dan ilustrasi menarik bagi anak (Colville-Hall \& O'Connor, 2006; Mahayanti et al., 2017). Colville-Hall \& O'Connor (2006) merinci bahwa maksimal big book hanya sebanyak 15 halaman, berisi cerita sederhana namun menarik, dengan beberapa kosakata yang terulang.

Penelitian terdahulu telah mengungkap manfaat big book dan storytelling bagi anakanak. Penelitian yang dilakukan oleh Tuerah (2021) membuktikan bahwa penggunaan big book memiliki pengaruh yang signifikan terhadap persepsi anak dalam kegiatan membaca, meningkatkan minat baca, dan pemahaman mereka terhadap isi bacaan. Selain itu, penggunaan big book di taman kanak-kanak juga disarankan karena berkesan bagi anak serta membantu perkembangan literasi mereka (Asha et al., 2020). Penelitian Wahyuningsih et al., (2019) menunjukkan bahwa big book juga bisa didesain menggunakan dwibahasa untuk mengenalkan literasi media bilingual pada konteks pendidikan sekolah dasar.

Pengunaan media yang menarik saja tentu tidak cukup jika tidak disertai dengan teknik mengajar yang tepat. Mendongeng (storytelling) merupakan salah satu strategi favorit 
guru anak usia dini dalam mengajar setelah pillihan metode permainan dan lagu disertai gerak (Arumsari et al., 2017). Pilihan tersebut sepertinya bukan tanpa alasan karena berdasarkan beberapa penelitian, metode mendongeng memang cocok diterapkan untuk anak-anak. Ariani dan Hariyono (2019) menyebutkan bahwa mendongeng merupakan teknik yang bisa membuat anak belajar tanpa menggurui mereka. Mereka menekankan bahwa ketika mendongeng, bukan hanya cerita yang penting namun juga cara bercerita. Cara bercerita inilah yang nanti bisa membantu anak belajar serta menambah perbendaharaan kosakata mereka. Terkait pembelajaran bahasa asing bagi anak-anak, penelitian Gaya (2017) mendukung bahwa penggunaan storytelling efektif dalam peningkatan literasi bahasa asing anak. Dalam penelitiannya, anak-anak tertarik untuk belajar serta mampu menguasai kosakata bahasa Inggris terkait bunga dan buah-buahan. Fahmi et al. (2020) mengobservasi bahwa teknik mendongeng merupakan salah satu strategi pengenalan literasi yang digunakan guru PAUD untuk menyiapakan anak masuk SD/MI.

Berdasarkan uraian di atas, big book dan storytelling memiliki potensi manfaat jika digabungkan dan diterapkan di taman kanak-kanak (TK). Namun, sayang sekali tidak semua guru TK mengenal media big book. Hal ini sebagaimana hasil wawancara peneliti dengan ketua ikatan guru Aisyiyah Bustanul Athfal (ABA). TK ABA merupakan TK yang berada dibawah naungan organisasi Muhammadiyah dan tersebar dibanyak wilayah Indonesia. Beliau menyatakan bahwa media itu tidak familiar karena memang selama ini tidak ada pelatihan terkait big book di wilayah Banjarmasin, terutama di organisasi yang beliau pimpin. Teknik storytelling telah mereka ketahui namun tidak sering digunakan karena lebih bertumpu pada penggunaan buku untuk menyampaikan materi. Karena tertumpu pada buku teks, maka pendidikan literasi pun terkesan kaku dan kurang menarik bagi anak. Pendidikan literasi bagi anak seharusnya bisa lebih menyenangkan dengan menggunakan media dan teknik yang merangsang motorik dan sensorik siswa, seperti meraba bentuk, membedakan warna, dan mengembangkan imaginasi.

Temuan tersebut merupakan sebuah kesenjangan menurut peneliti antara teori baik hasil penelitian dengan penerapan yang ada di lapangan. Untuk menjembatani kesenjangan tersebut, peneliti merancang penelitian ini dengan menggunakan desain penelitian pengembangan (design-based research). Dengan desain ini diharapkan para guru mendapatkan kesempatan untuk mengembangkan media big book mereka sendiri. Keterlibatan guru sangat penting karena mereka adalah pengguna media sehingga harus mengetahui cara membuat dan menggunakannya. Berdasarkan tujuan ini, maka ada dua pertanyaan yang ingin dijawab dalam penelitian ini, yaitu: 1) Bagaimana pengembangan big book storytelling yang tepat untuk mengajarkan literasi dwi bahasa bagi anak usia dini, dan 2) bagaimana respon guru dan anak dalam penggunaan media dan teknik tersebut?

\section{METODOLOGI}

Penelitian ini menggunakan desain penelitian pengembangan (design-based research). Desain ini dipilih karena bisa memberikan ruang bagi peneliti dan guru untuk berkolaborasi dalam memahami, mengekspolarasi, dan mendesain pembelajaran atau bahan ajar yang tepat guna (Anderson, 2005; Wang \& Hannafin, 2005). Kolaborasi ini penting karena jika kita ingin mendesain produk pembelajaran yang sesuai dengan kebutuhan lapangan maka harus terjadi interaksi, diskusi, dan negosiasi antara peneliti dan pengguna produk tersebut. Oleh sebab itu, tujuan dari penelitian pengembangan adalah memberikan intervensi sekaligus solusi dalam pembelajaran dan memvalidasi konsep teoritis dengan mengintegrasikannya pada praktik dilapangan (Papavlasopoulou et al., 2019).

Penelitian ini dilaksanakan di Banjarmasin, Kalimantan Selatan dengan sasaran kelompok kerja guru Aisyiyah Bustanul Athfal (TK ABA) atau yang biasa disebut sebagai IGABA. Menurut informasi dari ketua IGABA, ada 34 TK yang tersebar di wilayah ini. Tiap TK akan diminta dua peserta guru untuk mengikuti pelatihan sehingga total partisipan penelitian ini adalah 74 guru TK. Uji coba produk akan dilaksanakan di salah satu TK untuk 
melihat kebermanfaatan, kemudahan, dan efektivitas produk yang dikembangkan. Konteks waktu penelitian ini adalah pada masa pandemi COVID-19 sehingga terjadi banyak penyesuaian metodologi penelitian yang akan dibahas pada bagian hasil.

Penelitian ini menggunakan model Reeves (2020) untuk mengembangkan media big book storytelling. Visualisasi detail tahapan model tampak pada Gambar 1.

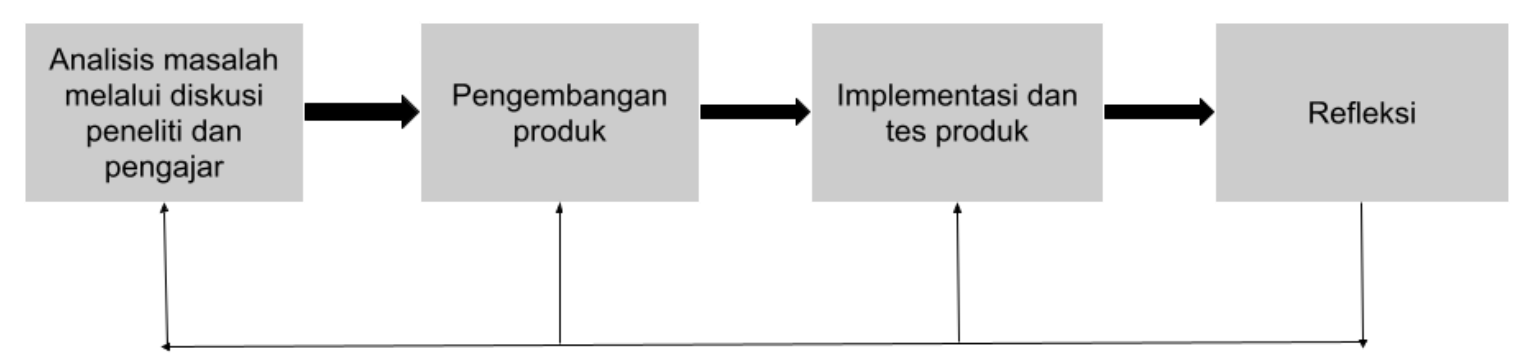

Gambar 1. Pengembangan Produk Berdasarkan Model Reeves (2006)

Berdasarkan Gambar 1 maka tahapan penelitian ini terbagi empat fase. Fase pertama adalah analisis masalah di lapangan. Instrumen pengumpulan data pada fase ini adalah wawancara. Wawancara dilakukan dengan ketua IGABA dan guru TK ABA. Pertanyaan wawancara terkait beberapa aspek seperti strategi yang dilakukan selama ini dalam mengenalkan literasi bagi anak, materi literasi di sekolah, ada atau tidak adanya literasi dwibahasa di sekolah-sekolah tersebut, dan kesiapan partisipan untuk terlibat penuh dalam kegiatan pengembangan big book storytelling. Wawancara dilakukan secara tatap muka dan sebagian melalui WhatsApp.

Tahapan berikutnya adalah pengembangan produk yang berbentuk pelatihan bagi guru-guru TK ABA. Peserta dilatih untuk membuat big book, menyusun cerita anak, dan strategi mendongeng menggunakan big book. Pada tahapan ini, observasi digunakan sebagai alat pengumpul data untuk melihat kemudahan pembuatan media. Partisipan aktif terlibat dalam kegiatan ini agar mereka bisa menguasai teknik pembuatan big book. Di tahapan pengembangan, salah satu produk dipilih untuk dijadikan sampel uji coba. Sampel ini akan dilakukan uji ahli (validasi produk). Validasi melibatkan dua ahli, yaitu ahli psikologi pendidikan dan juga ahli bahasa. Untuk ahli psikologi pendidikan, aspek yang dinilai adalah kualitas fisik media dan aspek pembelajaran dan psikologis. Sementara itu, ahli bahasa juga menilai aspek kualitas fisik disertai dengan penilaian aspek bahasa.

Pasca validasi, salah satu sekolah dipilih untuk tahapan implementasi dan uji coba produk. Pada kegiatan ini, anak-anak akan dilibatkan agar aspek kebermanfaatan, kemudahan, dan efektivitas produk bisa diobservasi. Guru akan menggunakan big book yang telah mereka buat dan menggunakannya di ruang kelas. Ketika guru mengajar, peneliti melakukan observasi terhadap respon anak-anak. Variabel yang diobservasi adalah semangat, perhatian, dan rasa senang atau puas.

Di fase terakhir, peneliti berdiskusi dengan guru untuk membuat refleksi. Berdasarkan catatan observasi dan rekaman video pembelajaran, peneliti mewawancara guru untuk mengkonfirmasi data yang mereka dapatkan serta menggali informasi terkait kelebihan dan kekurangan produk selama masa uji coba. Data-data ini akan digunakan untuk revisi dan penyempurnaan produk agar media yang dikembangkan bisa digunakan dan didesiminasi.

Sebagaimana diterangkan $\mathrm{di}$ atas, pengumpulan data pada penelitian ini menggunakan wawancara dan observasi. Data-data dari kedua instrumen tersebut bersifat kualitatif sehingga analisis data juga dilakukan secara kualitatif. Data wawancara akan didengarkan berulang-ulang, ditranskrip, dikodifikasikan, dan dimasukkan dalam tema-tema tertentu. Hasil data dari observasi juga akan dianalisis secara induktif (Braun \& Clarke, 2006). 


\section{HASIL DAN PEMBAHASAN}

Bagian ini menyajikan hasil penelitian berdasarkan tahapan pengembangan produk, yaitu 1) hasil analisis masalah, 2) pengembangan produk, 3) implementasi produk, dan 4) refleksi. Pembahasan hasil temuan dengan teori dan penelitian terdahulu akan terintegrasi pada tiap penjelasan tahapan. Pada bagian terakhir, implikasi hasil penelitian juga didiskusikan.

\section{Hasil Analisis Masalah}

Berdasarkan hasil wawancara dengan ketua IGABA, diketahui bahwa ada 44 TK ABA yang tersebar di wilayah Banjarmasin, namun hanya 34 saja yang masih aktif. Dari seluruh TK tersebut ada 170 guru. Guru-guru itu memiliki latar pendidikan yang beragam dan sebagian dari mereka bukan lulusan dari program studi pendidikan anak usia dini ketika awal bergabung. Namun beliau menegaskan bahwa hingga saat ini telah banyak dari mereka yang kuliah kembali untuk penyesuaian kualifikasi pendidikan. Beliau mencontohkan bahwa di TK tempat beliau bekerja, semua gurunya telah memiliki ijazah S1 PAUD. Mengetahui latar belakang guru sebelum penelitian dilakukan dianggap penting karena berpengaruh terhadap kinerja dan cara mengajar ketika media nanti akan diujikan (Andriana et al., 2018).

Wawancara dengan ketua IGABA dan guru menyatakan bahwa mereka belum familiar dengan big book. Pelatihan terkait media tersebut juga belum pernah diikuti. Berdasarkan keterangan ini maka peluang untuk pengembangan big book di TK ABA disambut antusias oleh ketua IGABA dan guru. Beliau mendukung dan menyediakan tempat untuk pelatihan serta peneliti diperbolehkan melakukan uji coba produk di sekolah. Terkait storytelling, guru mengakui bahwa beliau sesekali menggunakan teknik tersebut di dalam kelas. Namun, ketika pandemi, kegiatan storytelling hanya bisa dilakukan dengan cara guru bercerita dan merekam suaranya untuk kemudian didengarkan oleh anak di rumah masingmasing. Keterangan ini menunjukkan bahwa guru telah mengenal teknik storytelling sehingga dalam pelatihan nanti hanya diperlukan penguatan terhadap teknik tersebut. Temuan ini selaras dengan hasil penelitian terdahulu bahwa mendongeng/storytelling merupakan teknik mengajar yang sudah familiar di kalangan guru PAUD (Arumsari et al., 2017; Fahmi et al., 2020).

Analisis selanjutnya terkait dengan cara mengajar dan materi literasi yang diberikan selama ini. Dalam wawancara, ketua IGABA dan guru menerangkan bahwa selama ini mereka menggunakan berbagai metode dalam mengenalkan literasi seperti bercerita, menyanyi, dan melalui Majalah Bustanul Athfal. Terkait materi, anak biasanya diajarkan kosakata yang berhubungan dengan lingkungan sekitar atau benda-benda di dekat mereka. Materi diberikan sesuai dengan kemampuan dan tingkatan anak. Ketua IGABA juga menjelaskan bahwa di TK mereka bahasa Inggris telah dikenalkan namun dalam batasan yang sederhana. Misal, mereka belajar tentang warna, angka, alat transportasi dan sebagainya. Jadi, pembelajaran bahasa Inggris dibatasi pada kosakata (vocabulary). Hal ini menunjukkan bahwa TK ABA siap untuk menerima materi dwibahasa dan big book yang dikembangkan bisa membantu mereka dalam proses pendidikan bilingual.

Secara singkat, analisis masalah ini menyimpulkan bahwa pengembangan big book storytelling ini dibutuhkan oleh calon pengguna karena mereka belum mengenal media tersebut dan berharap bisa membuatnya sendiri. Teknik storytelling telah dikenal oleh partisipan sehingga bisa memudahkan proses pengembangan dan implementasi. Hal yang perlu dilakukan adalah penguatan teknik mendongeng yang tepat, memotivasi, dan bisa membangkitkan penyerapan siswa terhadap kosakata yang diajarkan. Hasil wawancara juga menunjukkan kesiapan TK ABA dalam menerima media pembelajaran dwibahasa.

\section{Pengembangan Produk}

Proses pengembangan produk dilakukan melalui pelatihan terhadap 74 guru TK ABA. Penelitian ini melibatkan perwakilan partisipan dari semua sekolah karena diharapkan bisa 
memberikan dampak yang lebih besar. Pelatihan dibagi menjadi dua, yakni pengembangan big book dan pelatihan storytelling. Peneliti berperan sebagai narasumber yang memberikan contoh dan tahapan pembuatan big book serta alat-alat yang diperlukan. Selama pelatihan, guru-guru dibagi menjadi kelompok kecil untuk membuat big book mereka sendiri. Gambar 2 menunjukkan antusiasme guru selama proses pembuatan big book.

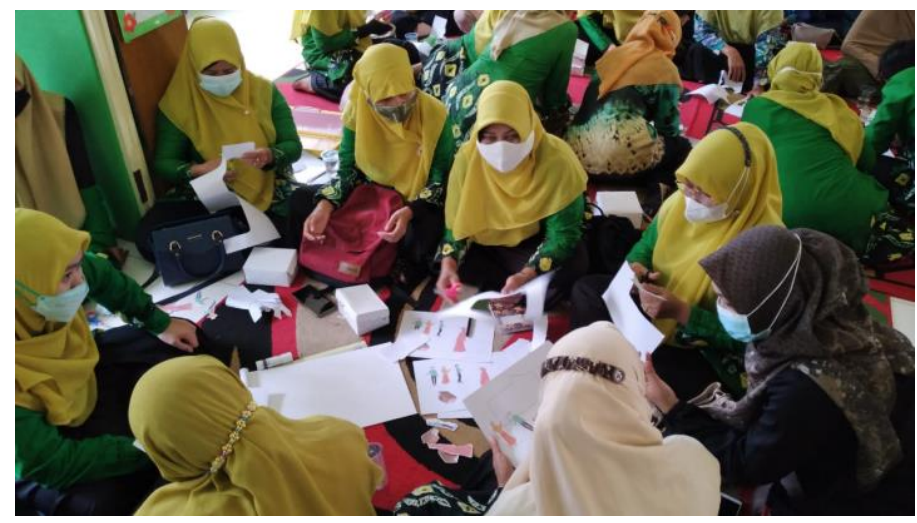

Gambar 2. Guru Membuat Big Book Secara Berkelompok

Big book dalam penelitian ini dibuat dengan menggunakan buku gambar ukuran A3. Pemilihan buku gambar didasarkan pada alasan mudah ditemui serta ukurannya yang cukup besar untuk digunakan di dalam kelas. Sebelum pelatihan, peneliti telah menyiapkan karakter/tokoh yang bisa digunakan dalam cerita. Karakter tersebut adalah Muhammad, Diyah, dan Aisyah. Karakter digambar sendiri dengan berbagai pose dan ekspresi, seperti berhadapan, menghadap ke depan, menghadap ke samping, tersenyum, terkejut, dan sebagainya. Masalah dalam pembuatan big book adalah ilustrasi. Peneliti menyadari bahwa tidak semua guru TK memiliki kemampuan menggambar yang baik. Dengan adanya readyprint karakter, guru diharapkan tidak mengalami kendala tersebut sehingga mereka hanya perlu menyiapkan cerita dan menempel karakter ke buku gambar A3. Dengan cara ini, pembuatan big book menjadi lebih sederhana dan bisa dilakukan oleh siapa saja. Terkait latar dan komponen gambar pendukung, misal tanaman, pemandangan, binatang, dan objek lainnya bisa secara mudah ditemukan di dalam Google Images. Namun, selama pelatihan beberapa guru kreatif membuat gambar mereka sendiri. Big book hasil pelatihan bisa dilihat pada Gambar 3.
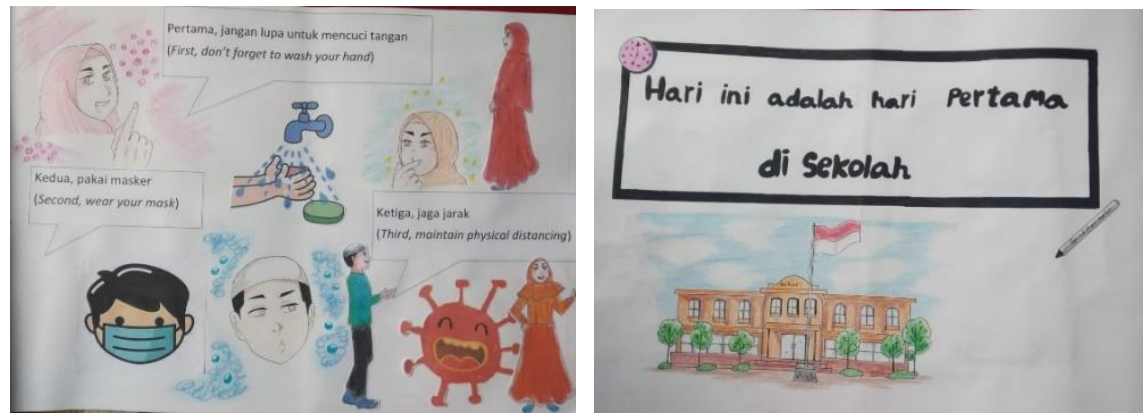

Gambar 3. Contoh Big Book yang Dibuat dalam Pelatihan

Gambar 3 adalah cuplikan dari cerita terpilih. Cerita tersebut dianggap menarik dan relevan dengan kondisi pandemi dan rencana new normal. Cerita itu berjudul hari pertama di sekolah yang menceritakan tentang kegiatan Muhammad dan Diyah. Mereka diingatkan oleh ibu guru untuk selalu mematuhi protokol kesehatan. Ilustrasi yang dibuat menarik. Sebagian dibuat dari template karakter yang disediakan dan sebagian digambar oleh guru sendiri untuk 
menambah estetika. Kosakata bahasa Indonesia dan bahasa Inggris yang digunakan juga sederhana dan terulang sebagaimana karakteristik sebuah big book (Colville-Hall \& O'Connor, 2006; Mahayanti et al., 2017). Dengan pertimbangan tersebut, big book ini dipilih sebagai sampel serta akan digunakan untuk kebutuhan validasi ahli dan implementasi.

Penilaian ahli diberikan dengan menggunakan angket. Angket ini merinci beberapa aspek yang perlu dinilai dengan rentang skala penilaian dari satu hingga empat. Angka satu mewakili sangat tidak setuju dan angka empat mewakili sangat setuju. Setuju dan tidak setujunya ahli terhadap item pernyataan yang diberikan menunjukkan skala kelayakan media dalam aspek tersebut. Pada uji ahli aspek psikologis dan pembelajaran, item-item yang dinilai adalah kesesuaian media dengan perkembangan intelektual anak, kemampuan media dalam memacu rasa ingin tahu anak, kesesuaian dengan perkembangan emosional anak, kesesuaian cerita dengan usia anak, kemudahan cerita untuk dipahami, dan efektivitas penyampaian pesan. Rerata nilai yang diberikan ahli adalah 3,5/4. Hal ini menujukkan bahwa media yang dikembangkan dalam kategori layak dan bisa digunakan dari aspek pembelajaran dan psikologis anak.

Ahli bahasa menilai tujuh item, yaitu kesesuaian bahasa yang digunakan dengan perkembangan anak, efektivitas kalimat, ketepatan tata bahasa, komunikatif, kebermanfaatan media untuk pengenalan literasi bahasa, konsistensi penggunaan istilah, dan kesesuaian kosakata bahasa Inggris dengan usia anak. Skor yang diberikan berada di rerata 3,7/4. Rerata ini sangat baik dan menunjukkan bahwa big book dan cerita yang dibuat oleh guru telah memenuhi kriteria aspek bahasa yang baik untuk anak usia dini. Aspek fisik media dinilai oleh kedua ahli. Item yang dinilai adalah kualitas bahan, keamanan bahan untuk digunakan anak, kesesuaian ukuran, kemenarikan ilustrasi, dan keterbacaan tulisan. Gabungan skor dari kedua ahli berada di rerata 3,7/4 yang menandakan bahwa kualitas fisik media berada di kategori sangat baik dan layak untuk digunakan.

Meskipun skor yang diberikan telah baik, para ahli tetap memberikan saran untuk revisi perbaikan. Menurut ahli psikologi pendidikan, sebaiknya karakter yang digunakan adalah karakter yang dekat dan dikenal anak. Misal, penggunaan karakter Spongebob atau Nusa Rara. Ahli bahasa juga menyarankan untuk menambahkan flashcard sebagai pelengkap untuk memudahkan pembelajaran kosakata. Kedua saran tersebut sangat bagus, namun hanya saran ahli bahasa yang digunakan untuk revisi produk. Saran ahli psikologi pendidikan belum bisa dilaksanakan atas pertimbangan hak cipta. Jika karakter komersial digunakan maka ditakutkan terjadi masalah terkait hak cipta atas penggunaan karakter tersebut dalam media yang dikembangkan oleh peneliti dan guru.

\section{Implementasi Produk}

Setelah revisi dilakukan, maka uji coba produk akan diterapkan di salah satu TK ABA. Namun sayang, ketika jadwal implementasi tiba, Pemberlakuan Pembatasan Kegiatan Masyarakat (PPKM) level 4 mulai diterapkan di Banjarmasin. Peraturan tersebut membatalkan wacana sekolah tatap muka. Hal ini menyebabkan perubahan metode uji coba yang semula di dalam kelas menjadi di rumah. Peneliti menghubungi guru TK yang akan melaksanakan home visit (kunjungan ke rumah siswa) untuk bisa menggunakan big book yang telah dibuat sebagai media belajar. Siswa yang seharusnya dalam jumlah banyak hanya bisa satu orang dan uji coba pun dilaksanakan hanya satu kali saja.

Tahapan mengajar yang dilakukan oleh guru adalah dengan mengenalkan kosakata bahasa Indonesia dan Inggris pada anak, memulai bercerita dan mengobrol, hingga evaluasi. Pada tahapan pengenalan kosakata, guru menggunakan flashcard yang disertakan. Dalam cerita "Hari Pertama di Sekolah" ada empat kosakata yang dikenalkan, yaitu sekolah (school), tangan (hand), masker (mask), dan air (water). Gambar 4 menggambarkan cara guru menggunakan flashcard dan Gambar 5 cara menggunakan big book. 


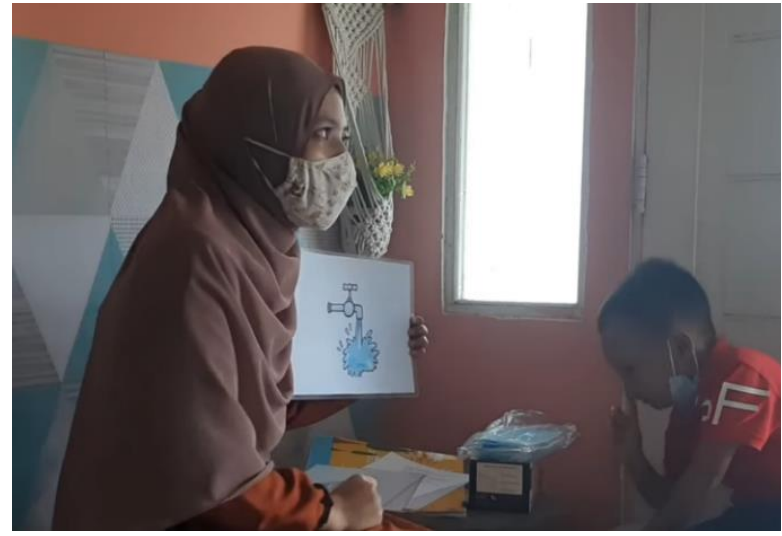

Gambar 4. Penggunaan Flashcard untuk Mengenalkan Kosakata

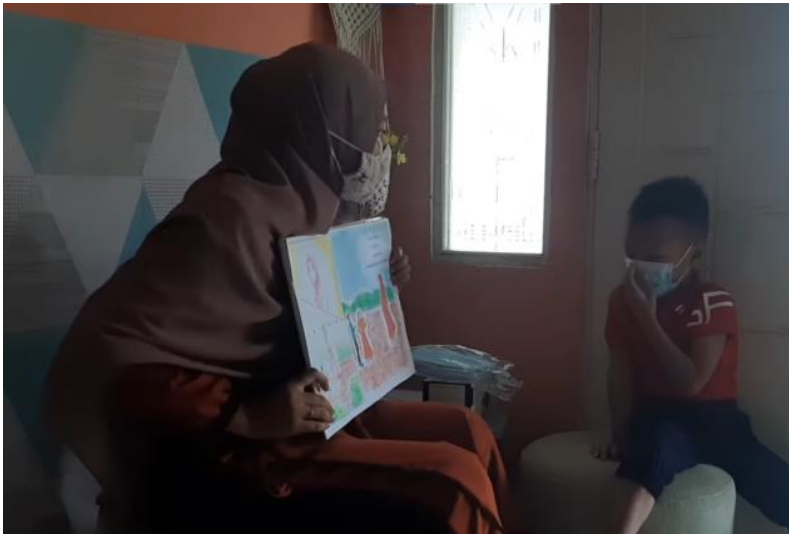

Gambar 5. Penggunaan Big Book Storytelling

Berdasarkan hasil observasi, dari segi perhatian tampak anak menunjukkan adanya minat untuk mengikuti pelajaran. Dia juga mau menyimak dan mendengarkan informasi yang diberikan oleh guru. Dari segi semangat, anak mau menjawab pertanyaan yang diberikan oleh guru yang menandakan dia cukup antusias dalam menanggapi cerita yang disampaikan. Aspek rasa senang/puas bisa terlihat dari ekspresi anak yang menunjukan kegembiraan dari awal kegiatan. Terkait penguasaan kosakata yang diberikan, di saat guru mengonfirmasi empat kata yang dikenalkan di awal, anak mampu mengulangi kembali kata-kata tersebut baik dalam bahasa Indonesia maupun bahasa Inggris. Hal ini senada dengan penelitian terdahulu bahwa penggunaan big book storytelling bisa secara efektif mengenalkan literasi dwibahasa bagi anak (Gaya, 2017; Tuerah, 2021). Selain itu, penggunaan flashcard juga bisa membuat anak mudah mengingat kosakata bahasa Indonesia dan Inggris. Sebagiamana yang disarankan oleh Hamidah (2020) dan Yansyah (2017) penggunaan flashcard memang efektif untuk digunakan bagi anak usia dini dalam pengenalan kata dan latihan membaca.

\section{Refleksi}

Pada tahapan ini, peneliti dan guru berdiskusi dan bernegosiasi tentang pengembangan serta penggunaan media yang telah dikembangkan. Refleksi dilakukan melalui wawancara via Zoom untuk menjaga protokol kesehatan di masa pandemi. Pada tahapan ini, guru diminta untuk mengingat kembali kemudahan, kebermanfaatan, dan efektifitas media yang dikembangkan. Selain itu, guru juga diminta untuk memberikan masukan terhadap big book storytelling ini untuk keperluan revisi.

Refleksi pertama berkaitan dengan kegiatan pelatihan yang diikuti oleh guru. Menurut beliau, pelatihan ini sangat membantu guru dalam hal pengembangan keahlian mengajar, terutama pembuatan media. Pelatihan seperti ini bermanfaat karena bisa diterapkan langsung oleh mereka pasca pelatihan. Alat-alat yang digunakan pun mudah dan juga tidak perlu bakat khusus untuk dapat membuat big book mereka sendiri. Pada saat pelatihan, guru juga merasa terjalin komunikasi dan kerja sama. Menurut para guru, hal ini juga bisa diterapkan di dalam kelas dengan membuat big book bersama siswa. Hal ini tentu saja merupakan peluang strategi mengajar yang kreatif dalam membangun atmosfir kelas yang menyenangkan. Nugroho (2017) menjelaskan bahwa pelatihan yang diperlukan guru adalah pelatihan yang sesuai dengan kebutuhan mereka. Oleh sebab itu, sangat penting untuk membuat pelatihan berdasarkan analisis masalah atau kebutuhan.

Refleksi kedua berhubungan dengan manfaat, kemudahan, dan efektivitas big book storytelling dalam memangkatkan literasi dwibahasa anak. Secara verbal, pendapat guru terkait aspek-aspek tersebut tergambar dalam kutipan wawancara berikut: 
“Nah untuk dari segi guru, ini dari segi sifat, manfaat maupun kepraktisan penggunaannya ini sangat mudah sekali, kenapa? karena dari sifatnya aja ini sudah mudah untuk kita bawa kemanamana. Jadi misal kita mau melaksanakan kegiatan tersebut di sekolah ataupun home visit ke rumah anak ini sangat mudah sekali untuk dibawa dari segi sifatnya. Manfaatnya cukup sangat jelas sekali, manfaatnya untuk merangsang pertumbuhan dan perkembangan anak dan kepraktisan tadi penggunaannya tadi. Untuk kepraktisan penggunaannya tadi itu sangat simple sekali karena inikan buku, cuman bukunya itu kita desain sedemikian rupa membuat daya tarik anak dari segi warna, itu warna-warna yang familiar di anak gitu. Bahkan menurut saya media big book ini sangat menarik dan bisa menjadi bahan pengganti gadget." (Data wawancara Ibu Maemunah)

Kutipan dari Ibu Maemunah (nama samaran) tersebut mengilustrasikan manfaat produk yang dikembangkan dengan deskripsi mudah dibawa, mudah digunakan, mampu merangsang pertumbuhan anak, dan bisa menjadi pengganti gadget. Dari segi perkembangan literasi, penggunaan big book storytelling yang disertai flashcard membuat anak bisa menikmati cerita dan pesan yang disampaikan. Melalui kegiatan storytelling, tampak bahwa anak bisa berbicara dengan guru dan aktif mengembangkan kemampuan bahasanya. Selain itu, pada tahapan evaluasi, anak juga bisa menyebutkan kembali kosakata yang dikenalkan baik itu dalam bahasa Indonesia maupun bahasa Inggris. Perolehan bahasa anak ini sangat penting untuk terus ditumbuhkan karena sebagaimana diungkapkan oleh Suggate et al., (Suggate et al., 2018) bahwa kemampuan literasi anak di usia dini bisa menjadi penentu kemampuan literasinya saat remaja. Guru dan orang tua harus menjadi role model dalam penanaman literasi melalui pemilihan media yang menarik dan penggunaan bahasa sederhana ketika berinteraksi dengan anak (Rajudin \& Sugianto, 2018). Oleh sebab itu, big book storytelling bisa menjadi alternatif bagi anak dan orang tua ketika mendongeng di sekolah dan di rumah.

Refleksi terakhir, berkaitan dengan kekurangan atau saran dari guru untuk meningkatkan kualitas big book storytelling. Guru menyatakan bahwa sebenarnya tidak ada media yang sempurna dalam pembelajaran. Menurut guru, sebagus apa pun medianya tetap saja diperlukan peran pengajar dalam memanfaatkannya secara maksimal. Berdasarkan ingatannya sendiri ketika mengajar anak dengan big book, dia merasa bahwa big book lebih fokus pada rangsangan visual dan aural. Dia menyarankan harusnya ada juga rangsangan sentuhan, seperti ketika dia membuka halaman pertama dan ada gambar pohon maka sebaiknya pohon tersebut bisa disentuh. Penggunaan realia dan pop-up book (buku timbul) bisa menjadi lanjutan dari pengembangan produk ini. Big book berbentuk pop-up bisa memberikan stimulasi yang lebih banyak terhadap berbagai indra anak. Mahliatussikah (2018) menjelaskan bahwa semakin banyak indra yang dilibatkan dalam proses belajar anak, maka akan semakin baik pula ingatan mereka terhadap materi yang diajarkan.

\section{Implikasi Penelitian}

Temuan penelitian ini berimplikasi pada pengajaran pendidikan literasi dwibahasa anak usia dini. Pertama, pendidikan literasi sebaiknya diterapkan sejak dini. Hasil perhitungan indeks Alibaca Nasional menunjukkan bahwa aktivitas literasi Indonesia masih berada di kategori rendah (Solihin et al., 2019). Dalam laporan tersebut, salah satu dimensi yang mempengaruhi literasi adalah dimensi Culture, yaitu kebiasaan yang membentuk habitus literasi. Dari 34 provinsi yang ada di Indonesia, 29 provinsi berada dikategori rendah untuk dimensi culture, termasuk provinsi-provinsi di Kalimantan. Oleh sebab itu, kebiasaan membaca harus dimulai sejak kecil agar anak mulai mencintai buku dan bahasa. Big book storytelling bisa menjadi alternatif untuk menciptakan habitus literasi di sekolah dan di rumah.

Implikasi selanjutnya pada pendidikan dwibahasa di PAUD. Bahasa asing bisa dikenalkan kepada anak dengan syarat sesuai usia perkembangannya. Kosakata yang dikenalkan pun adalah kosakata sehari-hari, dekat dekat dengan anak, dan bisa sering digunakan atau didengar (Gaya, 2017). Dalam penelitian ini, empat hingga lima kosakata 
sudah cukup bagi anak. Hal terpenting dalam pelaksanaan pendidikan dwibahasa adalah konsistensi. Guru dan orang tua harus bekerja sama jika ingin membuat anak menguasai secara baik dua atau lebih bahasa secara bersamaan. Rajudin dan Sugianto (Rajudin \& Sugianto, 2018) menyarankan bahwa guru sebisa mungkin memberikan materi yang mudah dipahami dan simpel bagi anak. Orang tua bisa membantu proses perolehan bahasa dengan cara menemani anak menggunakan bahasa Inggris atau menggunakan media berbahasa Inggris. Buku-buku cerita dwibahasa bisa menjadi pilihan bagi orang tua dan anak dikala senggang. Penggunaan flashcard juga bisa memudahkan guru dan orang tua untuk pengenalan kosakata baru bagi anak (Hamidah, 2020; Yansyah, 2017).

Terakhir, pembelajaran literasi terhadap anak sebaiknya dengan metode yang menarik dan menyenangkan. Storytelling atau mendongeng disarankan untuk digunakan karena bisa merangsang imajinasi anak ketika cerita dibacakan. Namun harus digarisbawahi, bahwa teknik bercerita yang baik harus diperhatikan agar anak bisa bersemangat dalam belajar dan mendengarkan (Ariani \& Hariyono, 2019). Storytelling harus disertai dengan intonasi, ekspresi muka, variasi suara, dan gestur yang sesuai dengan cerita agar anak terstimulasi untuk membayangkan isi cerita (Dewi, 2020). Selama implementasi, guru bercerita sambil mengobrol dengan anak. Melalui cara ini, anak terlihat aktif karena dia merasa diperhatikan dan selalu diikutsertakan selama proses storytelling. Libatkan anak-anak untuk ikut bergerak, melihat gambar, dan jika bisa menyentuh objek dalam cerita untuk memperbanyak keterlibatan panca indra (Mahliatussikah, 2018). Oleh sebab itu, agar guru semakin cakap dalam mendongeng, sangat disarankan untuk melibatkan mereka dalam berbagai pelatihan baik yang digalakkan oleh pemerintah maupun sekolah itu sendiri.

\section{SIMPULAN}

Big book storytelling bisa menjadi solusi untuk mengenalkan literasi dwibahasa untuk anak usia dini. Big book bisa dikembangkan dengan empat tahapan, yaitu analisis masalah, pengembangan produk, implementasi, dan refleksi. Hasil validasi menunjukkan bahwa big book storytelling dianggap layak untuk digunakan baik dari segi pembelajaran, psikologis, dan bahasa. Berdasarkan hasil penerapan, big book storytelling mudah untuk digunakan dan mampu merangsang minat anak mendengarkan cerita sekaligus membantu mereka mengingat kosakata baru, baik dalam bahasa Indonesia maupun bahasa Inggris. Anak tampak semangat dan antusias dalam belajar dengan menggunakan media ini. Singkatnya, big book storytelling memenuhi kriteria manfaat, kemudahan, dan efektivitas untuk pengajaran literasi.

\section{UCAPAN TERIMA KASIH}

Ucapan terima kasih kami sampaikan kepada Lembaga Penelitian dan Pengabdian (LP2M) Universitas Muhammadiyah Banjarmasin yang telah mendanai penelitian ini. Kami juga mengucapkan terima kasih kepada Ikatan Guru Aisyiyyah Bustanul Athfal (IGABA) wilayah Banjarmasin yang telah bersedia menjadi mitra penelitian.

\section{DAFTAR PUSTAKA}

Anderson, T. (2005). Design-based Research and its Application to a Call Centre Innovation in Distance Education. Canadian Journal of Learning and Technology / La Revue Canadienne de l'apprentissage et de La Technologie, 31(2). https:// doi.org/10.21432/T26K60

Andriana, J., Sumarsih, \& D., D. (2018). Kinerja Guru PAUD Ditinjau Dari Kualifikasi Pendidik, Pengalaman Mengajar, Dan Pelatihan. Jurnal Ilmiah Potensia, 3(2), 18-23. https:// ejournal.unib.ac.id/index.php/potensia/article/download/2521/2683 
Ariani, L., \& Hariyono, D. S. (2019). Storytelling Sebagai Metode Dalam Mengembangkan Kemampuan Berbahasa Pada Anak Prasekolah. Prosiding Seminar Nasional \& Call Paper Psikologi Pendidikan, 36-44.

Arumsari, A. D., Arifin, B., \& Rusnalasari, Z. D. (2017). Pembelajaran Bahasa Inggris pada Anak Usia Dini di Kec Sukolilo Surabaya. Jurnal PG-PAUD Trunojoyo: Jurnal Pendidikan Dan Pembelajaran Anak Usia Dini, 4(2), 133. https://doi.org/10.21107/jpgpaud.v4i2.3575

Asha, N., Siraj, S., Ismail, H., Omar, R., Samad, S. A., \& Ninari, E. F. (2020). Penggunaan Big Book Dalam Kalangan Guru Tadika Untuk Perkembangan Literasi Kanak-Kanak. Jurnal Pendidikan Awal Kanak-Kanak Kebangsaan, 9(ii), 106-112.

Bialystok, E. (1999). Cognitive complexity and attentional control in the bilingual mind. Child Development, 70(3), 636-644. https:// doi.org/10.1111/1467-8624.00046

Braun, V., \& Clarke, V. (2006). Using thematic analysis in psychology. Qualitative Research in Psychology, 3(2), 77-101. https:// doi.org/10.1191/1478088706qp063oa

Colville-Hall, S., \& O'Connor, B. (2006). Using big books: A standards-based instructional approach for foreign language teacher candidates in a PreK-12 program. In Foreign Language Annals (Vol. 39, Issue 3, pp. 487-506). https://doi.org/10.1111/j.19449720.2006.tb02901.x

Dewi, N. A. R. (2020). Early Childhood Pre-Reading Literacy Skills Based On The Application Of Storytelling Methods. BELIA: Early Childhood Education Papers, 9(1), 73-75. https://journal.unnes.ac.id/sju/index.php/belia/article/view/44829

Fahmi, F., Syabrina, M., Sulistyowati, S., \& Saudah, S. (2020). Strategi Guru Mengenalkan Konsep Dasar Literasi di PAUD Sebagai Persiapan Masuk SD/MI. Jurnal Obsesi : Jurnal Pendidikan Anak Usia Dini, 5(1), 931-940. https://doi.org/10.31004/obsesi.v5i1.673

Gaya, T. (2017). Enhancing children's English vocabulary acquisition through digital storytelling of happy kids kindergarten of Palembang. International Journal of Educational and Pedagogical Sciences, 11(11), 980-989. https://doi.org/10.20319/pijss.2018.33.980989

Hamidah, J. (2020). Implementasi Media Flash Card dalam Menanamkan Nilai Karakter Religius pada Pembelajaran Membaca Permulaan Anak Usia Dini. Silampari Bisa: Jurnal Penelitian Pendidikan Bahasa Indonesia, Daerah, Dan Asing, 3(1), 1-14. https://doi.org/10.31540/silamparibisa.v3i1.751

Hopp, H., Vogelbacher, M., Kieseier, T., \& Thoma, D. (2019). Bilingual advantages in early foreign language learning: Effects of the minority and the majority language. Learning and Instruction, 61, 99-110. https:// doi.org/10.1016/j.learninstruc.2019.02.001

Izzak, A. (2009). Bilingualisme dalam perspektif pengembangan Bahasa Indonesia. Mabasan, 3(1), 15-29. https://doi.org/10.26499/mab.v3i1.98

Jayanti, D., \& Sujarwo, A. (2019). Bilingual Education In Indonesia: Between Idealism and the Reality. Script Journal: Journal of Linguistic and English Teaching, 4(1), 12. https://doi.org/10.24903/sj.v4i1.271

Kieseier, T. (2021). Bilingual advantage in early EFL pronunciation accuracy of German 4thgraders. International Journal of Bilingualism, 25(3), 708-726. https:// doi.org/10.1177/1367006921996811

Mahayanti, N. W. S., Artini, L. P., \& Jannah, N. (2017). The effect of big book as media on students' reading comprehension at fifth grade of elementary school in SD Laboratorium Undiksha Singaraja. International Journal of Language and Literature, 1(3), 2549-4287. https:// doi.org/10.23887/ijll.v1i3.12544

Mahliatussikah, H. (2018). Bermain, cerita, dan menyanyi (BCM) dalam pembelajaran bahasa Arab. Prosiding Konferensi Nasional Bahasa Arab IV, 57-72.

Montoya, S. (2018). Defining Literacy: UNESCO. In GAML Fifth Meeting. 
Nugroho, P. J. (2017). Pengembangan Model Pelatihan Inovatif untuk Meningkatkan Kompetensi Guru Sekolah Dasar Daerah Terpencil. Jurnal Ilmu Pendidikan, 26(2), 101115.

Papavlasopoulou, S., Giannakos, M. N., \& Jaccheri, L. (2019). Exploring children's learning experience in constructionism-based coding. Computers in Human Behaviour, 99(1), 415-427. https://doi.org/10.1016/j.chb.2019.01.008

Rajudin, R., \& Sugianto, A. (2018). Children ' s English vocabulary acquisition in EFL primary school context of Golden Christian school Palangka Raya. Proceedings of the 2nd INACELT (International Conference on English Language Teaching), 16-17.

Reeves, T. C. (2020). Design research from a curriculum perspective. In J. van den Akker, K. Gravemeijer, S. McKenney, \& N. Nieveen (Eds.), Educational Design Research (pp. 79102). Routledge. https:// doi.org/10.4324/9780203088364-14

Solihin, L., Utama, B., Pratiwi, I., \& Novirina. (2019). Indeks Aktivitas Literasi Membaca. In Mobile Devices: Tools and Technologies (Issue 2). Pusat Penelitian Kebijakan Pendidikan dan Kebudayaan, Kementerian Pendidikan dan Kebudayaan.

Suggate, S., Schaughency, E., McAnally, H., \& Reese, E. (2018). From infancy to adolescence: The longitudinal links between vocabulary, early literacy skills, oral narrative, and reading comprehension. Cognitive Development, 47, 82-95. https:// doi.org/10.1016/j.cogdev.2018.04.005

Tuerah, I. J. C. (2021). "Story Time!": Coping with low-motivated students using big book. Script Journal, 6(1), 81-91.

Wahyuningsih, Y., Harsono, N., \&amp; Setyaningsih. (2019). Bigbook Design Bilingual in the Context of Culture West Java. Jurnal Pendidikan Sekolah Dasar, 2(229), 75-80. https://doi.org/10.21831/didaktika.v2i2.28100.g13085

Wang, F., \& Hannafin, M. (2005). Design-Based Research and technology-Enhanced Learning Environment. Educational Technology Research \& Development, 53(4), 5-23. https://doi.org/10.1007/BF02504682

Yansyah. (2017). Helping young learners to learn audi discrimination by using flashcards. LET: Linguistics, Literature and English Teaching Journal, 5(1), 75-81. https:// doi.org/10.18592/let.v5i1.1424

Yona Wahyu, Nono Harsono, S. (2019). Bigbook Design Bilingual in the Context of Culture West Java. Jurnal Pendidikan Sekolah Dasar, 2(229), 75-80. https://doi.org/10.21831/didaktika.v2i2.28100 